\title{
資料研究報告
}

\section{港川フィッシャ一遺跡（沖縄県八重瀬町）の 更新世人骨出土情報に関する新たな知見}

諏訪 元 $^{1 *}$, 藤田 祐樹 ${ }^{2}$, 山崎 真治 $^{2}$, 大城 逸朗 ${ }^{3}$, 馬場 悠男 ${ }^{4}$, 新里 尚美 ${ }^{5}$, 金城 達 ${ }^{5}$, 海部 陽介 ${ }^{4}$, 松浦 秀治 ${ }^{6}$

\author{
1 東京大学総合研究博物館 \\ 2 沖縄県立博物館・美術館 \\ 3 扣きなわ石の会 \\ 4 国立科学博物館人類研究部 \\ 5 沖縄県八重瀬町教育委員会 \\ 6 打茶の水女子大学自然人類学研究室
}

(平成 23 年 7 月 27 日受付，平成 23 年 10 月 6 日受理)

\begin{abstract}
要 約
港川フィッシャ一遺跡からは個体骨 4 体分を含む「港川人骨」が知られている。人骨と共に採集された 木炭片から $18250 \pm 650 \mathrm{BP}$ と $16600 \pm 300 \mathrm{BP}$ の未較正 ${ }^{14} \mathrm{C}$ 年代測定値が得られているが, 出土情報の詳細が 出版されていなかったことから，人骨と年代值との関係は定かでなかった。そこで，今回，現存する調査 記録と出土情報を確認・分析し，特に，大山盛保と渡辺直経らによる 1970 年の「港川人骨」の発掘・採集 について可能な限り明らかにした。東京大学に保管されてきた港川フィッシャ一遺跡出土の動物骨と人骨 に関連して，従来から，番号付きの資料カードが作成されて招り，出土グリッド，採取年月日，人骨片の 部位などが記されている。これらの詳細情報と大山盛保による手記と図，および渡辺直経の記述は互いに 整合性が高く，以下のことを確認寸ることができた。1）港川 2 号・3 号・4 号人骨は，主として，渡辺が 沖縄訪問中の 1970 年 8 月 21 日〜 23 日の間にグリッド $\mathrm{A} 2 / \mathrm{A} 3 \sim \mathrm{C} 4$ の範囲から採取・発掘されたものであ る。2）港川 1 号人骨は，主として 1970 年 9 月〜 11 月に，グリッド $\mathrm{C} 5 / \mathrm{C} 6 \sim \mathrm{D} 6$ とかけて大山が発見・採 取したものである。3 ${ }^{14} \mathrm{C}$ 年代測定の対象となった木炭片は 2 号・3号・4 号人骨とイノシシ骨多数を産出 した粘土層から採取したものと推論できる。また，今回の再評価調査の過程で，港川フィッシャ一遺跡と 山下町第一洞穴遺跡の人骨について，若干数の未発表資料を確認した。そこで，両遺跡関連の人骨資料に ついて改めて標本リストを作成した。
\end{abstract}

キーワード：更新世人類化石，琉球列島，港川フィッシャ一遺跡，山下町第一洞穴遺跡，年代・出土情報

*東京大学総合研究博物館

干 113-0033 東京都文京区本郷 7-3-1

E-mail: suwa@um.u-tokyo.ac.jp

Published online 22 November 2011

in J-STAGE (www.jstage.jst.go.jp) DOI: 10.1537/asj.110727

(C2011 The Anthropological Society of Nippon 


\title{
New insights on the excavation and chronological status of the Late Pleistocene Minatogawa human fossils from Okinawa Prefecture
}

\author{
Gen Suwa ${ }^{1 *}$, Masaki Fujita ${ }^{2}$, Shinji Yamasaki², Itsuro Oshiro ${ }^{3}$, Hisao $\mathrm{Baba}^{4}$, \\ Naomi Shinzato ${ }^{5}$, Tatsuru Kinjo ${ }^{5}$, Yousuke Kaifu', and Shuji Matsu'ura ${ }^{6}$ \\ ${ }^{1}$ The University Museum, The University of Tokyo \\ ${ }^{2}$ Okinawa Prefectural Museum and Art Museum \\ ${ }^{3}$ Okinawa Ishi no Kai \\ ${ }^{4}$ Department of Anthropology, National Museum of Nature and Science, Tokyo \\ ${ }^{5}$ Yaese Town Board of Education, Okinawa \\ ${ }^{6}$ Laboratory of Physical Anthropology, Ochanomizu University
}

(Received 27 July 2011; accepted 6 October 2011)

\begin{abstract}
The Minatogawa Fissure site on Okinawa Island is known from its Late Pleistocene human fossils represented by four partial skeletons. Radiocarbon dates of $18250 \pm 650 \mathrm{BP}$ and $16600 \pm 300 \mathrm{BP}$ have been reported on associated charcoal, but interpretations of the age of the fossils have been clouded from a paucity of published contextual data. We therefore set out to critically examine all information available to us, with the aim to unambiguously clarify the chronological status of the Minatogawa fossils. Up to 57 information cards accompany the fossil assemblage, with excavation grid, date, and bone part data. The details of this information are highly congruent with several other sources, Seiho Oyama's personal memoir and excavation charts, Naotune Watanabe's brief reports, and the inscriptions on the fossil bones themselves. We conclude that the following reliable inferences can be made. Most parts of the Minatogawa II, III, and IV individuals were collected/excavated between August 21 to 23, 1970, during N. Watanabe's presence at the site, predominantly from grids A2/A3 to C4. The Minatogawa I individual was discovered by S. Oyama, between September and November, 1970, from grids C5/6 to D6 lower in the fissure site. The dated charcoal samples were recovered in the clay layer that contained individuals II, III, and IV and abundant wild boar remains. During our investigation, we also newly identified a few human fossil bones in the 1968/69 Minatogawa Fissure and Yamashita-cho Cave I collections. We present here an updated listing of these and the 1970 Minatogawa human fossil collections.
\end{abstract}

Key words: Late Pleistocene human fossils, Ryukyu Islands, Minatogawa Fissure site, Yamashita-cho Cave I site, excavation and chronological context

\section{はじめに}

日本列島に抢ける更新世人類化石の発見は, 1950 年代 後半から 1960 年代初頭の鈴木尚らによる静岡県三ヶ日 只木採石場と浜北根堅洞穴の人骨資料の発見以来(鈴木, 1962，1966），その充実が期待されてきた。しかし，九州 以北の人骨資料で近年の年代分析的検討を経て縄文時代 より前の更新世由来とされているものは，今のところ浜 北人骨だけである（Kondo and Matsu'ura, 2005）。

琉球列島では，1960 年代初頭に，多和田真淳と高宮廣 衛らの調査活動を通じ，更新世むで遡る可能性のある遺 跡や人骨の存在が強く認識されるようになった。そして
多和田らの働きかけにより，1967 年から 74 年までの間, 東京大学の鈴木尚, 渡辺直経らとの合同調査が数回行わ 机た（鈴木，1975; 渡辺，1980; 野原，1996）。中でも著 名な成果としては沖縄島の山下町第一洞穴遺跡出土の子 供人骨と，大山盛保ならびに合同調査チームによる，港 川フィッシャ一遺跡出土の一連の化石人骨の発見があ る。山下町第一洞穴では人骨の直上層の木炭から 32100 \pm 1000 BP（TK-78）の未較正 ${ }^{14} \mathrm{C}$ 年代測定値が得られて扮 り (Kobayashi et al., 1971; 高宮ほか, 1975)，現在日本最 古の人骨資料と久なされている。港川フィッシャ一遺跡 からは 9 点の四肢骨片を中心としたいわゆる「上部港川 人骨」（馬場，2002）と全身に渡る個体骨 4 体分を含む 
「港川人骨」（Suzuki and Hanihara, 1982）が知られている。 後者については，人骨と共に採集された木炭片から $18250 \pm 650$ BP (TK-99) と $16600 \pm 300$ BP（TK-142）の未 較正 ${ }^{14} \mathrm{C}$ 年代測定値が得られている（Kobayashi et al., 1971, 1974）。その後，宮古島のピアンザアブと久米島の 下地原洞穴から人骨化石が発見され（佐倉，1985; Oshiro and Nohara, 2000; 大城, 2001), 共伴物から更新世に遡る 年代值が示されている（Matsu'ura, 1999; 松浦・近藤, 2000)。最近では, 石垣島の白保竿根田原洞穴出土の人骨 複数から直接, 更新世末の ${ }^{14} \mathrm{C}$ 年代測定值が報告されて いる（Nakagawa et al., 2010）。しかし，今のところ，山下 町第一洞穴遺跡と港川フィッシャ一遺跡出土の人骨資料 が，それぞれ，本邦最古と最古の substantialな（頭骨や 個体骨など情報量の多い）更新世人類化石である。

東アジアに拈けるホモ・サピエンス集団の拡散と変遷 については，各地域の後期更新世の化石資料が不十分な ため，有効な仮説構築と検証が実質的に難しい現状があ る。そうした中, 琉球列島を含む日本列島の substantial な更新世人類化石の充実は，日本列島における人の由来 に関する進化的論考を可能にするだけでなく，アジア地 域に打ける現代人集団形成史の全体像の理解にも大きく 寄与すると思われる。港川フィッシャ一遺跡と山下町第 一洞穴遺跡から出土した人骨の古人類学的評価について は，既に発表されている諸成果を基盤に（例えば，Suzuki and Hanihara, 1982; Suzuki, 1983; Trinkaus and Ruff, 1996; Baba et al., 1998; 馬場，2000，2002），現在さらに検討が 進められている（例えばAnthropological Science 119 巻 2 号掲載の諸論文)。

本稿は, 沖縄県立博物館・美術館の研究者らによる港 川フィッシャー遺跡出土人骨の出土情報に関する新たな 調査活動と, 東京大学総合研究博物館, 拈茶の水女子大 学ならびに国立科学博物館に収蔵されてきた関連資料の 再検討の成果の一部を報告するものである。この情報整 理活動の一環として, 2010 年 9 月から 2011 年 6 月までに 著者らによる 3 回の研究会と関連調査が執り行われ, 今 回の報告をまとめるに至った。本稿の目的は，第一には， 港川人骨の調査・発見の経緯と出土情報について既存の 出版情報以上に明示し, 同人骨に関する今後の理解と評 価に寄与することにある。第二には，若干の未発表標本 を含め，港川フィッシャ一遺跡扣よび山下町第一洞穴遺 跡出土の人骨を整理目録化し, 日本列島に打ける更新世 人類化石の今後の研究に資することにある。

\section{調査略史}

ここでは本稿に必要と思われる事項だけをまとめ，よ り包括的な要約は別稿に譲る。山下町第一洞穴遺跡に ついては, 1962 年に多和田と高宮らが初めて発掘し, 1968 年 12 月末から翌 1 月にかけて鈴木・渡辺らとの合同 調査が実施され（渡辺が代表者の科学研究費補助金によ る）人骨化石（子供の大腿骨と脛骨）が発見された（渡 辺，1971，1973，1980; 高宮ほか, 1975)。港川フィッシャー では，大山盛保が 1968 年の 1 月と 3 月に後に「上部港川 人骨」として知られる骨片複数を発見したことが契機と なり，山下町第一洞穴遺跡と並行して 1968/69 年に発掘 調査が実施された。港川フィッシャ一遺跡の当時の調査 結果としては新たな人骨の発見は認識されず（渡辺, 1971，1973)，1970年 8 月に大山が再び人骨を発見するま で大きな進展はなかった。大山の調査記録（未出版）と 今回検討した他の情報をまとめると，同年 8 月 10 日〜 12 日に頭骨, 下顎片, 脛骨, 大腿骨, 骨盤を大山が発 見し東京大学に連絡，8月 20 日に渡辺が沖縄に到着し, 8 月 21 日〜 23 日の 3 日間に人骨 3 個体分を含む化石骨が 発掘・採取された（下記参照）。このときの発掘者は渡 辺・大山の汪か, 多和田真淳, 野原朝秀と文化財保護委 員会関係者とされている（野原，1996）。大山はその後も 調査を継続し（11月末まで），さらに 1 個体以上の人骨 の発見に至った。1970年 12 月末から翌 1 月にかけ，鈴 木・渡辺・田辺義一らとの合同調査が実施され（田辺が 代表者の科学研究費補助金による), 動物骨と人骨若干数 が追加発見された。

\section{港川人骨の出土等に関するこれまでの出版情報}

港川人骨は琉球石灰岩層中に形成された高さ約 $20 \mathrm{~m}$, 幅 $1 \mathrm{~m}$ 汪どのフィッシャ一内の堆積物下方から発見され て打り，発掘ならびに出土情報について鈴木らが簡単に 記している（Suzuki and Hanihara, 1982）。発掘にあたり， フィッシャーの長軸にそって水平方向に $\mathrm{x}$ 軸, 上下方向 に $\mathrm{y}$ 軸が設定され， $\mathrm{x}$ 軸方向 $2 \mathrm{~m}, \mathrm{y}$ 軸方向 $1 \mathrm{~m}$ のグリッ ドが設けられた（Suzuki and Tanabe, 1982; 鈴木, 1983）。 Suzuki and Tanabe（1982, p. 4) ではグリッドごとの人骨 出土位置が模式的に図示されている (http://www.um.utokyo.ac.jp/publish_db/Bulletin/no19/no19002.html に本図を 含む Suzuki and Hanihara, 1982 のモノグラフ全体が公開 されている)。これによると，それぞれの人骨が出土した 主なグリッドは，1 号人骨（Minatogawa I） は C5/C6， 2 号人骨（Minatogawa II）は C4/C5，3 号人骨（Minatogawa 
III）は B2/B3/C4，4号人骨（Minatogawa IV）は A2/A3/C3/ C4 である。下顎 A， B，C はそれぞれグリッドD6，C3，C4 に図示されている。

同じモノグラフの松浦の年代学的分析と論考では, 1 号， 2 号，4号，下顎 A 以外に，グリッドD6出土の 4 点 の四肢骨片が報告されている（Matsu'ura, 1982）。これら の分析資料は，当時，松浦が鈴木から直接受け取ったも のである。Matsu'ura（1982）はさらに30 点あまりの動 物骨を比較対象として分析しているが，これらは長谷川 善和から提供を受けた 1970/71 年調査の発掘資料であ る。出土情報としては Suzuki and Tanabe（1982）で示さ れているグリッド設定が踏襲されているが，A列の西側 のグリッドは Z 列として記されている（長谷川・松岡， 2002 参照)。

\section{港川フィッシャー遺跡・山下町第一洞穴遺跡出土人骨の 所蔵と標本リストの更新}

港川フィッシャー遺跡および山下町第一洞穴遺跡から 出土した人骨は, 鈴木尚を中心に整理と研究が進められ, 1980 年代以来, 主に東京大学総合研究資料館（現東京大 学総合研究博物館）に収蔵されてきたが，2007 年 11 月 に港川人骨の一部（3 号人骨，4号人骨）が沖縄県立博物 館・美術館に移管された。これは，沖縄県における調査 研究活動の振興に資するため, 東京大学総合研究博物館 と沖縄県立博物館・美術館による協力的な「分担管理」 体制に移行したものである。今回は，今後の学術研究に 混乱が生じないよう，両館に保管されている港川人骨の 統一的な標本リストを表 1 としてまとめた。この表には， 港川フィッシャ一遺跡拈よび山下町第一洞穴遺跡から出 土した人骨のほか，鈴木（1975）が記載した沖縄諸島出 土の人骨（片） 3 点を掲載した。「標本名」は東京大学総 合研究博物館の縄文時代人骨に適用されている方式（遠 藤・遠藤，1979）を採用した。今回の目録には Suzuki and Hanihara（1982）に掲載されていない港川人骨（片）若 干数を加えてある。追補したものの一部は，鈴木尚が自 身の研究資料として保管していたものであり，断片骨で あるか 1970 年末〜翌年初頭の調査で追加発見された小 骨・破片骨である。他の未報告標本は，今回の港川フィッ シャ一遺跡および山下町第一洞穴遺跡関連資料の評価活 動中に確認したものである。

1970年発掘の港川フィッシャ一遺跡人骨の個体数につ いては最小 5 個体，最大 9 個体と推定されている（Suzuki and Tanabe, 1982)。最大個体数は任意の推定になるので, ここでは個体数の蓋然的範囲として以下のような考察を
行った。従来から，最小個体数は女性が 3 体（2号・3 号・4 号人骨），男性は 1 号人骨と下顎 B（Suzuki and Tanabe, 1982）の注か，遊離腓骨片（Baba and Endo, 1982） を含めると計 3 個体分が報告されている。しかし，腓骨 片の一つの遊離四肢骨「P」については 1 号人骨に属する 可能性を完全に否定することはできない。一方，今回の 目録に含めた未報告頭骨片は華奢な前頭骨片からなり， 化石化の状態が 3 号人骨（頭骨を欠く） と異なることを 考慮すると，4個体目の女性の頭骨片の可能性がある。ま た， Kaifu et al.（2011）の評価によると下顎の B と D は 同一男性個体の右・左下顎片の可能性が高く，これを認 めれば 1 号人骨以外の男性の下顎は 1 個体 (B 和よびD), 女性の下顎は 2 個体（A と）となる。これらの女性下顎 が 2 号・3 号・4 号人骨もしくは上記頭骨片個体の一部で あるかどらかは定かでないので，女性の個体数は $3 \sim 6$ となる。また，四肢骨化石から集計した場合，女性の可 能性のある四肢骨の最小個体数は第 3 中手骨 $(2$ 号・3 号・ 遊離四肢骨「D」）もしくは第 5 中手骨（3 号・遊離四肢 骨「J」・今回新たにリスト化した「D6 水洗い」）により 3 個体，これらより小型な第 4 中手骨（遊離四肢骨「G」） を認めると最小個体数は 4 となる。以上から，1970年発 掘の港川フィッシャ一人骨資料の個体数は男性が $2 \sim 3$, 女性が $4 \sim 6$ の可能性が高い。

山下町第一洞穴遺跡の追加発見骨片（表 1）について は，既報（Suzuki, 1983）の大腿骨資料に接合することに より，骨体遠位部をほぼ補うものである。

\section{港川人骨出土情報の確認と新たな検討成果}

港川人骨の出土情報については，先述の Suzuki and Tanabe（1982）による模式図と簡単な記述だけが報告さ れていた。今回は，現在，我々が分析することができる 2 種の情報源を主として検討した。1つは，人骨ならびに 伴出した動物骨に付随する資料カード情報である。この カード情報は従来から東京大学に保存されていたもの で，整理番号，出土グリッド，採取年月日，人骨の部位， 接合する破片等の情報が記されている。もら 1 つは，大 山盛保が調査記録として残した手記と図で，一部の人骨 の発見日と出土位置が記録されている。

東京大学のカードは 1971 年 8 月から 1975 年ごろまで に鈴木尚と研究支援者らが作成したもので，化石骨（複 数）が当初収められていた袋ごとに作成され，内容とし ては次の $1 \sim 4$ の情報を含む（当時の研究補佐員に当た り，今回確認）。1）カードごとに付された番号（以下「整 理番号」)，即ち同一の袋にあった骨片全てに同じ整理番 


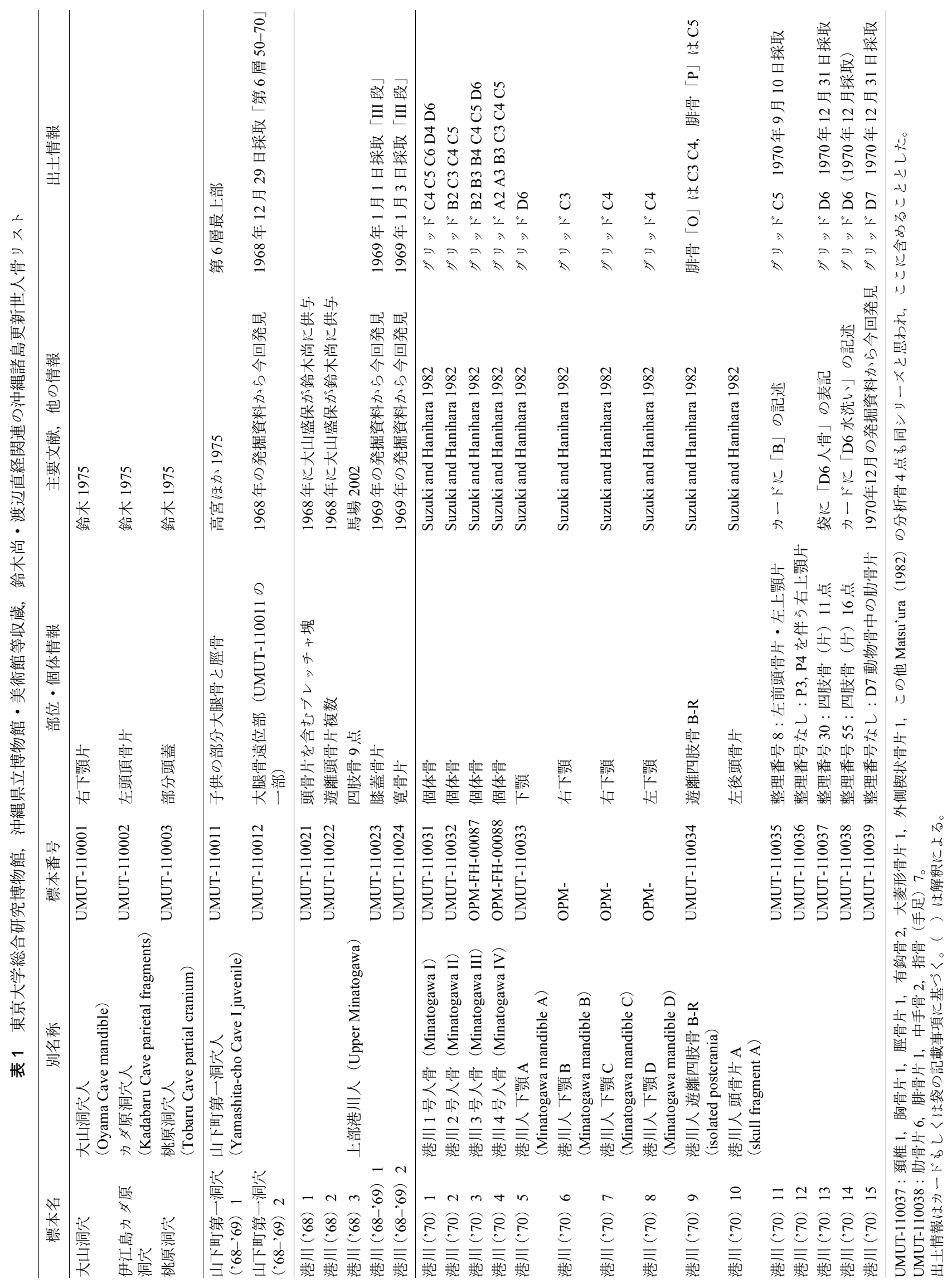




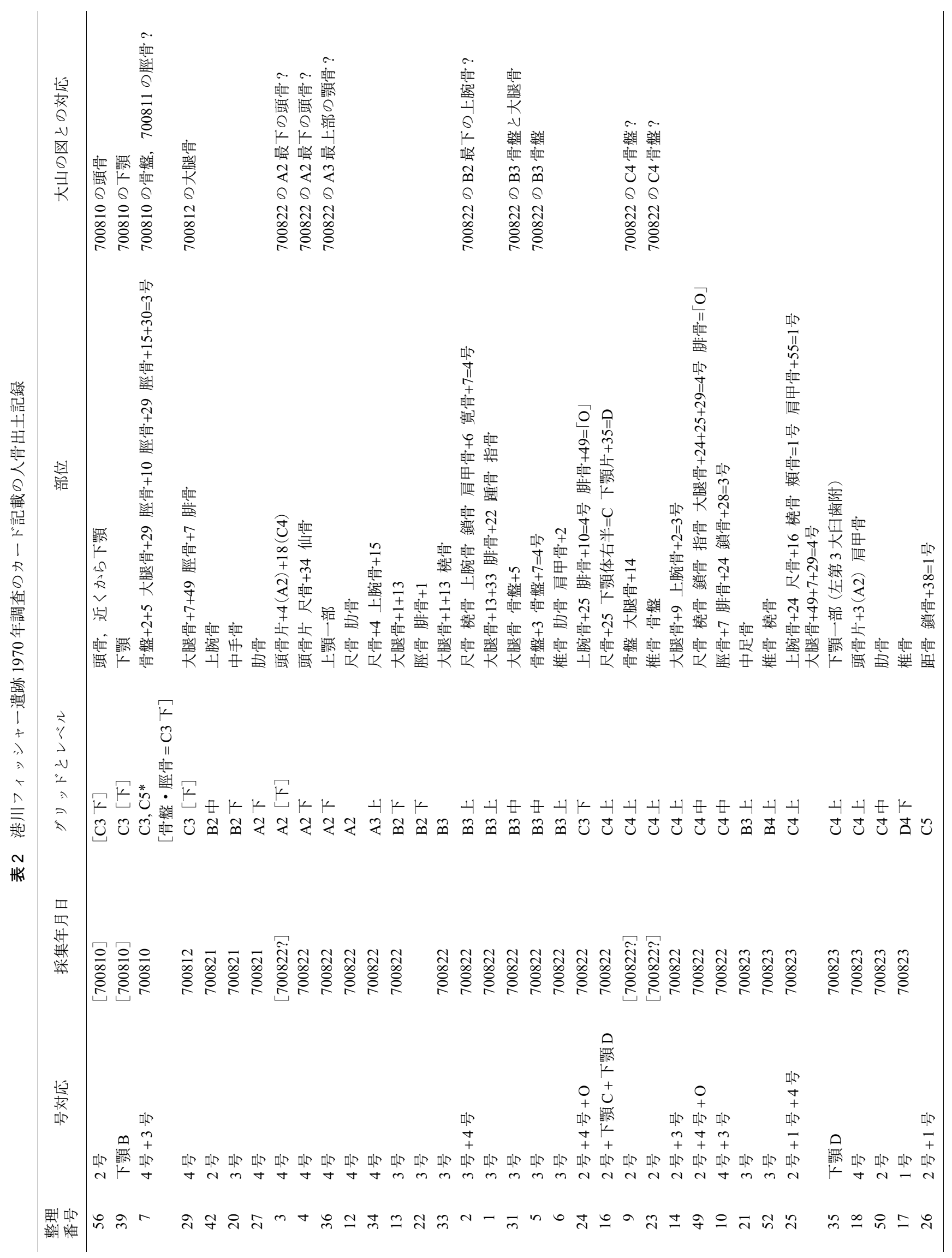




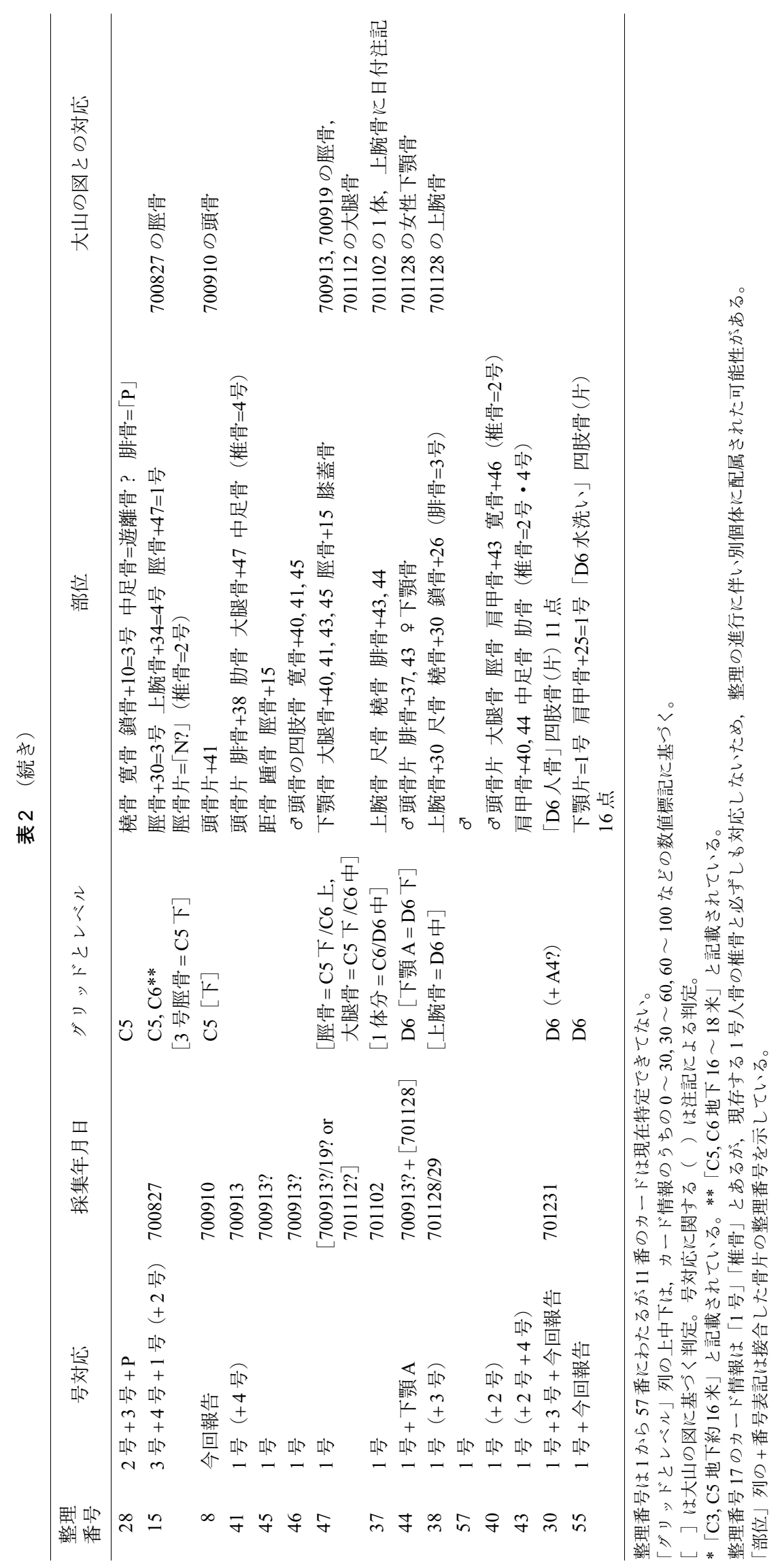


号が与えられたことになる，2）その袋に入っていた人骨 （破片）の部位表記（整理・復元が進むにつれて追記され ている)，3）別の整理番号を持つ人骨破片との接合状況, 4）グリッドと採取年月日情報。ただし，採取日は必ずし も記載されておらず, 記されているものでは 1970 年 8 月 21 日〜23日の間の日付が多い。な拈, 整理番号は 1 番から 57 番におよび, 現在は番号一つが確認できていない（表 2 参照)。

今回明確になったのは, 渡辺が 1970 年 8 月の沖縄訪問 中の調査期間に取り上げられたと思われる人骨の殆どに ついて，出土グリッドと採取年月日の記載がカード情報 として存在することである。さらに，大山による人骨出 土位置を示す図が 2 つ残されており，1つは渡辺ら発掘 時の 8 月 22 日付のものである。もら 1 つの図には, 渡辺 到着前の 8 月 10 日〜 12 日と訪問後の 8 月末から 11 月末 の間に発見された人骨の一部について出土位置が示され ている。詳細は別稿にて報告される予定であるが，いず れの図も上述のカード情報などと整合的である。そこで,
本稿では各情報を統合し, 出土位置（グリッド）と発掘 年月日を表 2 にまとめた。また，表 3 では個体骨 1 号〜 4 号について, 骨の部位ごとに出土情報をまとめた。一部 の人骨片には先述の整理番号を書き写したと思われる注 記があり，数は少ないが，骨の部位などカード情報と整 合的である（表 3）。

さらに，今回まとめた出土情報を図に示した。カード に記されたグリッド情報（表 2）に基づき図1（上）に整 理番号（カード）とグリッドの対応関係を示した。この 図に打ける整理番号の位置は，そのまま，人骨と周辺の 化石採取状況を示すと解釈できる。人骨だけが該当する 整理番号が 23 個，人骨と動物骨の双方を伴ら番号が 27 個, 現在は動物骨だけが確認されている番号が 6 個ある。 これらの整理番号付きカードに伴ら, 人骨周辺から発見 されたと思われる動物骨 300 点近くが東京大学総合研究 博物館に保存されている。以上により，8月 23 日までに 採取された化石骨の出土グリッドは, フィッシャーの下 方では大方 A4〜D4 Dでと考兄らる。

表 3 港川 1 号〜 4 号人骨の部位別グリッド出土情報

\begin{tabular}{|c|c|c|c|c|c|c|c|c|}
\hline \multirow[b]{2}{*}{ 部位 } & \multicolumn{2}{|c|}{1 号 } & \multicolumn{2}{|c|}{2 号 } & \multicolumn{2}{|c|}{3 号 } & \multicolumn{2}{|c|}{4 号 } \\
\hline & 整理番号 & $\begin{array}{c}\text { グリッド・ } \\
\text { レベル }\end{array}$ & 整理番号 & $\begin{array}{c}\text { グリッド・ } \\
レ ヘ ゙ ル ~\end{array}$ & 整理番号 & $\begin{array}{c}\text { グリッド・ } \\
\text { レベル }\end{array}$ & 整理番号 & $\begin{array}{c}\text { グリッド・ } \\
\text { レベル }\end{array}$ \\
\hline 頭骨 & $2540414457 ?$ & $\begin{array}{l}\text { (frag)C4up } \\
\text { (frag)D6 }\end{array}$ & 56 & C3low & & & 341836 & A2low C4up \\
\hline 下顎 & 4755 & C5/6 D6 & & & & & & \\
\hline 椎骨 & 17304055 & D4low D6 & $\begin{array}{l}1523252840 \\
43\end{array}$ & C4up C5 & 652 & B3up B4up & 410344143 & $\begin{array}{l}\text { A2low A3up } \\
\text { C4mid }\end{array}$ \\
\hline $\begin{array}{l}\text { 肋骨 } \\
\text { 胸骨 }\end{array}$ & $404143+55$ & D6 & 50 & C4mid & 6 & B3up & 1227 & A2 A2low \\
\hline 鎖骨 & $2638+$ & C5 D6 & $49+50$ & C4mid & $2+10+28$ & B3up C4mid C5 & 34 & A3up \\
\hline 肩甲骨 & 2540434455 & C4up D6 & & & $2+6$ & B3up & 18 & C4up \\
\hline 上腕骨 & $3037+38$ & C6/D6 D6 & 242542 & $\begin{array}{l}\text { B2mid C3low } \\
\text { C4up }\end{array}$ & 214 & B3up C4up & $515+34+$ & A3up C5? \\
\hline 橈骨 & 303738 & C6/D6 D6 & 252849 & C4up-mid C5 & 23352 & B3up B3 B4up & & \\
\hline 尺骨 & 3738 & C6/D6 D6 & 162549 & C4up-mid & 2 & B3up & 41234 & A2 A2low A3up \\
\hline 手骨 & & & 49 & C4mid & 20 & B2low & & \\
\hline 寛骨 & 40414546 & & 928 & C4up C5 & 531 & B3mid & 257 & B3up C3low \\
\hline 大腿骨 & 4041434547 & $\mathrm{C} 5 / 6$ & $9+14$ & C4up & 1133133 & $\begin{array}{l}\text { B2low B3up } \\
\text { B3mid B3 }\end{array}$ & 724252949 & $\begin{array}{l}\text { C3low } \\
\text { C4up-mid }\end{array}$ \\
\hline 膝蓋骨 & 47 & $\mathrm{C} 5 / 6$ & & & & & & \\
\hline 脛骨 & 15404547 & $\mathrm{C} 5 / 6$ & & & $7+15+2230+$ & $\begin{array}{l}\text { B2low C3/C5 } \\
\text { C5low A4/D6 }\end{array}$ & $7+10+29+$ & C3low C4mid \\
\hline 腓骨 & 3738414344 & C6/D6 D6 & & & 12238 & $\begin{array}{l}\text { B2low B3up } \\
\text { D6? }\end{array}$ & $4102429+$ & $\begin{array}{l}\text { A2low C3low } \\
\text { C4mid }\end{array}$ \\
\hline 足骨 & 414345 & & 26 & C5 & 121 & B3up & & \\
\hline
\end{tabular}

各骨の出土グリッド・レベル情報の根拠：番号（整理番号）はカード情報，番号+はカード情報と骨注記，番号（イタリック）は骨注記だけに基づく。 グリッド・レベル欄の up, mid， low はそれぞれグリッド内の上，中，下。 整理番号 11 のカードは現在特定できていない。整理番号 40，41，43，45，46，57 はグリッド情報がない。

整理番号 53 はグリッドA4 4 号との表記だが, 部位情報は「骨片」とだけあり, 現存人骨との対応が確認できないため除外。

整理番号 54 はグリッドA4 4 号との表記が動物骨付随のカードにだけあり，部位情報の vertebraeが実在骨部位と対応しないため除外。

整理番号 17 のカード情報は「1号」「椎骨」とあるが，現存する 1 号人骨の椎骨と必ずしも対応しないため，整理の進行に伴い別個体に配属された 可能性がある。 
図 1 （下）には，整理番号付きカードに記されている 人骨（破片）それぞれを1点としてグリッド図にプロッ トした。同じ骨が複数の破片として別のカードに記載さ れている場合は，それら全てを別々に示した。従って， 図 1 （下）は当該の人骨片全ての拈扎と出土分布と みなすことができる。この結果は Suzuki and Tanabe （1982）に掲載された図の人骨のグリッド分布と（C6 と
D6を除き）酷似している。しかし，各骨（片）が発見さ れたグリッド内の水平位置については，今回の調査では ほとんど特定することができなかった。また，C5/C6 と D6 の出土情報は大山の部分的な記録によるところが多 く，少数のプロット情報をもとに同一の整理番号を持つ 骨（片）を配分した。

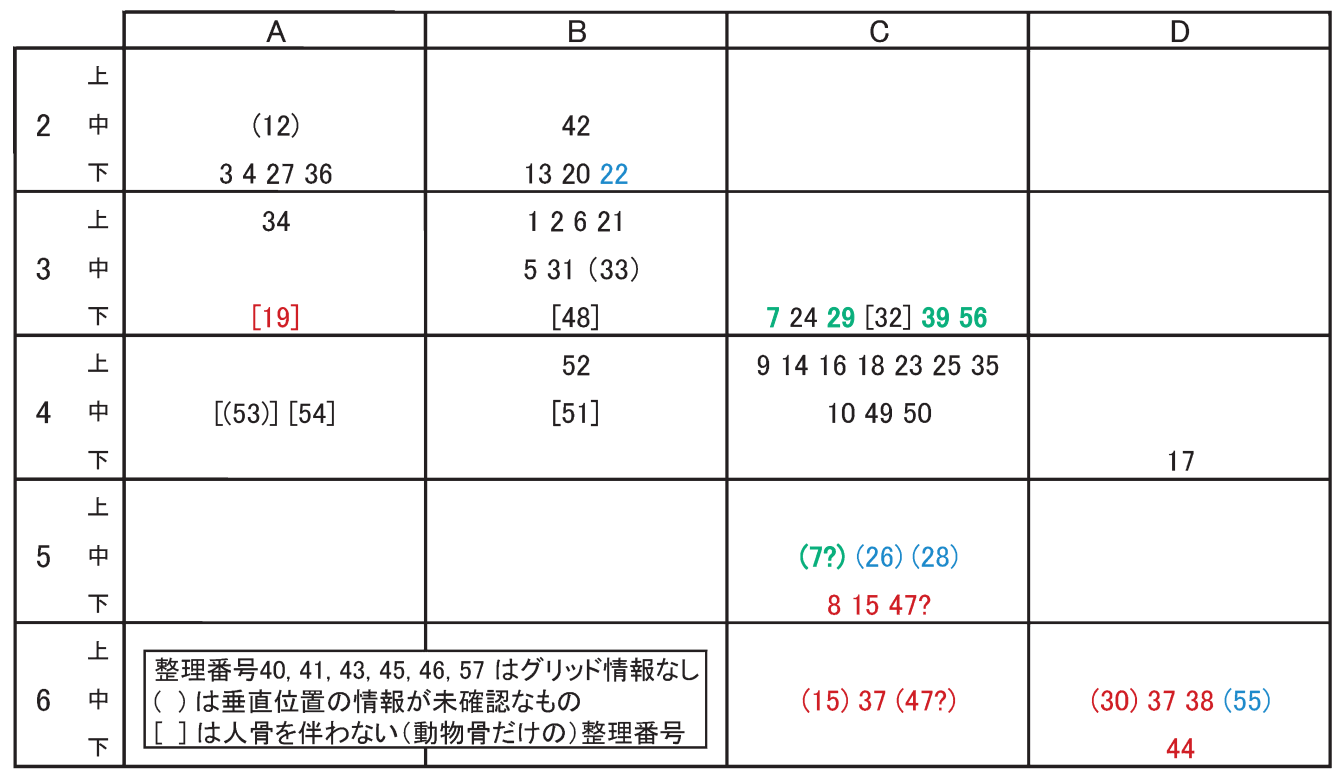

\begin{tabular}{|c|c|c|c|c|c|}
\hline & & A & B & C & D \\
\hline 2 & $\begin{array}{l}\text { 上 } \\
\text { 中 } \\
\text { 下 }\end{array}$ & $\begin{array}{c}(\bullet \bullet) \\
\bullet \bullet \bullet \bullet \bullet \bullet ~\end{array}$ & $\begin{array}{c}\odot \\
\diamond \diamond \diamond \diamond\end{array}$ & & \\
\hline 3 & $\begin{array}{l}\text { 上 } \\
\text { 中 } \\
\text { 下 }\end{array}$ & $\bullet \bullet$ & 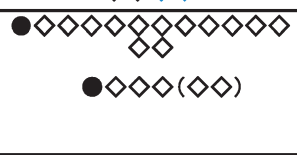 & 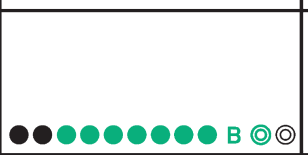 & \\
\hline 4 & $\begin{array}{l}\text { 上 } \\
\text { 中 } \\
\text { 下 }\end{array}$ & & $\diamond \diamond$ & 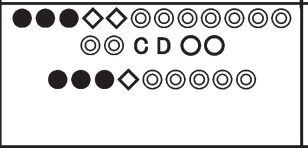 & 0 \\
\hline 5 & $\begin{array}{l}\text { 上 } \\
\text { 中 } \\
\text { 下 }\end{array}$ & ৩: 4号 & & $\begin{array}{c}(0 \odot \bigcirc \bigcirc \diamond)(\diamond ?) \\
800 \diamond \diamond\end{array}$ & \\
\hline 6 & $\begin{array}{l}\text { 上 } \\
\text { 中 } \\
\text { 下 }\end{array}$ & $\begin{array}{l}\text { (O): 2号 } \\
\text { O: 1号 } \\
\text { A D : 下: 顎骨A〜D } \\
\text { 8: 今回報告の頭骨片 }\end{array}$ & & $(0000) 00$ & $\begin{array}{c}(\diamond ?) \\
\text { ०००००००(0000) } \\
\text { A ००० }\end{array}$ \\
\hline
\end{tabular}

図 1 人骨の出土位置 (人骨と動物骨に付随する資料カードの記載情報から再構成)。上図は整理番号とグリッドの対応関係，下図 は人骨（片）の位置を示している。同一カードに複数の人骨情報が記載されていることが多く，カード (整理番号) 数よりも 人骨の出土点数が多い。カードには $\mathrm{cm}$ 単位の垂直位置が記されており，その情報に従って上・中・下の 3 段に分割して図示 した。水平位置については，ごく一部しか情報を確認して扣らず，本図では示していない。数值拈よび記号の色は，緑が 8 月 21 日以前に発見されたもの, 黒が 8 月 $21 \sim 23$ 日, 赤が 8 月 24 日以後に発掘されたもの, 青は日付情報が確認できなかったものを 示す。整理番号 17 のカード情報は「1 号」「椎骨」とあるが，現存する 1 号人骨の椎骨資料と必ずしも対応しないため，別個 体に配属された可能性がある。 


\section{考察}

港川フィッシャー遺跡における 1970 年の調査に関す る以上の情報整備の成果から, 出土状況と層序・年代に ついて幾点かの考察が可能である。まずは, 渡辺の沖縄 訪問中（8月）に取り上げられた人骨は 2 号・3号・4 号 人骨であることを改めて確認することができた。渡辺は 「厚さ約 1.5 米の粘土層中水平距離約 5 米の範囲から 3 体 分と思われる人骨片が出土した」として扣り（東京大学 放射性炭素年代測定装置委員会の資料カード，下記参 照)，図 1 (下）の A2/A3 から C4 までの傾斜した領域が 渡辺らが発掘した粘土層の括扣よその範囲に相当すると 思われる。一方，1970 年 9 月以降に大山盛保が発見した 1 号人骨は，より下位から出土したと結論できる。

渡辺はまた，別稿で

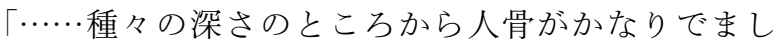
た。そのとき気がついたのは，人骨の出る粘土層に， 細かな木炭片がかなりちらばっていることです。 ……(中略) ……これを極力採集して測定した結果, $18250 \pm 650$ 年といら年代がでました。……(中略） ……山下町の方は殆どシカばかりといらのと極めて 対称（ママ）的です。ところが，この港川からも， 8 月に来た時には，かなり下の方からシカの角が一 本でて拈ります。しかも，重要なことには，人骨が 出るところに入っているのです。……(中略）…… つまり，第一次調査の所見では猪だけというららに み充ましたが，8月の調査によって，シカの数は少 ないのですが，存在することがわかりました。8月 には，かなり多数の人骨が収集されましたが，その 後，さらに大山氏が，丹念にここを調べているらち に，11月にはまたかなり多くの人骨を収集されまし た。…. (中略) …々れる，8月に掘った所より， かなり下の方から出たという事でした。」

と述べており（渡辺，1973，p. 3），上にまとめた人骨出 土状況の検討結果と以下に述べる動物骨の所見と整合す る。渡辺（1973）が言及しているシカ角化石は今回の整 理番号付きカードに伴ら標本中には特定できなかった が，渡辺の記述が信頼性の高いものであることは大山の 1970 年 8 月 22 日付の図が示している。大山の図には渡辺 が言及していると思われるシカ角化石がグリッド C4の 下部に木炭片らしき黒影と共に記されている。また，整 理番号付きカードに伴ら大型哺乳類（イノシシとシカ）
化石全 100 片余りのらち, 今回の調査では 88 点をイノシ シと同定したのに対して，シカと同定できたものは 8 点 だけであった。このシカ骨 8 点のうち，渡辺の 8 月沖縄 訪問中の日付を伴ったものは 1 点あり, グリッド B 3 下部 から 8 月 23 日に出土したとされている。他のシカ化石に ついては，1点は日付を伴わないがグリッド C5 から, 残 り 6 点は出土グリッド情報がないが 1 号人骨片と同じ整 理番号を持ち（6 点中の 2 点は 9 月 13 日の日付を伴う） C5/C6 から出土した可能性が高い。従って, 渡辺（1973） の記述は現存する動物骨の出土情報とも整合する。

最後に, $18250 \pm 650 \mathrm{BP}(\mathrm{TK}-99)$ と $16600 \pm 300 \mathrm{BP}(\mathrm{TK}-$ 142 )の放射性炭素年代測定值と人骨化石との関係ついて 今回の検討結果をまとめる。渡辺は東京大学の放射性 炭素年代測定装置委員会へ提出したTK-99 の資料カード （1970 年 9 月 17 日付）に，木炭片の採取年月日は 1970 年 8 月 22 日, 出土状況については「……比高 20 米余の断崖 に露出している幅 1 米前後のフィシャー（ママ）内，地 下 $15 \sim 16$ 米の粘土層より, 去る 8 月 10 日大山盛保氏に より人骨片が発見され，渡辺が渡沖して 8 月 $21 \sim 23$ 日 同処の発掘を行った。厚さ約 1.5 米の粘土層中水平距離 約 5 米の範囲から 3 体分と思われる人骨片が出土した。 本粘土層中に散在する木炭片で，人骨と同時代であるこ とは疑いない。と報告している。これは渡辺の記述（渡 辺，1973）扣よび大山の 8 月 22 日付の図の情報とも整合 する。TK-99の年代值は 1970 年 12 月 18 日付で報告され ている。TK-142 の資料カード（日付はない）には「沖縄 本島具志頭村港川採石場フィシャー（ママ）内の人骨を 出土した土層中の木炭片」とだけ記されており，1973 年 12 月 11 日付で年代值が報告されている。従って, TK-142 は 1970 年 8 月に採集された試料の残部であるか 1970 年 末から 1971 年初頭の調査時に採集された可能性がある。 以上から，TK-99 の $18250 \pm 650 \mathrm{BP}$ の測定值は 2 号・ 3 号・4 号人骨が出土した粘土層から採取した木炭片の 年代值と考光られる。TK-142の $16600 \pm 300$ BP はその追 試として得られた年代值と思われるが，試料の出土情報 は確認できていない。

\section{まとめ}

港川フィッシャ一遺跡出土の個体骨 4 体分を含む「港 川人骨」の出土情報は, Suzuki and Hanihara（1982）に簡 単に記されているが, その詳細は必ずしも明らかでなかっ た。今回は現存する出土記録を可能な限り再検討した。 東京大学に保管されてきた化石骨の付随情報と大山盛保 の調査記録，また渡辺直経の記述を比較検討し，以下の 
認識を得た。1）1970 年 8 月 10 日〜 12 日に大山盛保が 2 号・3 号・4 号人骨の一部を発見し, 渡辺直経の沖縄訪問 を待った。2）渡辺が沖縄に到着後の 8 月 21 日〜23日の 3 日間に 2 号・3号・4 号人骨の殆ど全ての人骨片が取り上 ゲられた。3）これらの人骨は，主として，グリッド A2/ A3からC4までの粘土層から出土したと思われる。4) 1 号 人骨は, 主として 1970 年 9 月〜 11 月に, グリッド C5/C6 から D6にかけて大山が発見・採取したものである。5） $18250 \pm 650$ BP（TK-99）の放射性炭素年代測定值は 2 号・ 3 号・4 号人骨とイノシシ骨多数を出土した粘土層から採 取した木炭片の年代值と推論でき， $16600 \pm 300$ BP（TK142）の年代值はその追試と思われる。

\section{謝辞}

今回の情報整理プロジェクトは, 沖縄県立博物館・美術 館を中心とした古人類調査の一環として執り行われたもの である。沖縄の古人類調査に多大なご支援を下さってきた 沖縄県立博物館・美術館の白保台一館長, 牧野浩隆元館長, 沖縄県立博物館・美術館への改組を担った宮城清志元館長 に改めて感謝の意を表したい。大山盛保氏の調査ならびに 記録について全面的にご教示くださった大山盛弘氏，大山 盛稔氏，大山盛正氏の多大な貢献なくして今回の成果は有 り得なかった。ここに記して深く謝意を表したい。今回の 成果は, 東京大学拈よび国立科学博物館関係, ならびに沖 縄県在住の多くの先輩先生諸氏, 長谷川善和, 遠藤萬里, 赤 澤威, 木村賛, 山口敏, 佐倉朔, 新田重清, 知念勇, 金武 正紀，土肥直美のご指導の賜物であり，港川人骨ならびに 他の先史・古人類・古生物研究へのご功績に敬意を表し, 各 氏に感謝の意を表したい。本資料報告をまとめるに当たり, 鈴木忠生氏ならびに東京大学と国立科学博物館にて鈴木尚 の研究支援に携わっていた高橋昌子, 遠藤美子, 西沢弘恵, 比田井民子の諸氏から数多くの貴重な情報をいただいた。 厚く御礼申し上げたい。東京大学放射性炭素年代測定室の 吉田邦夫教授からは年代測定カードの情報を提供いただい た。今回の資料整理活動の一部には佐宗亜衣子, 坂上和弘, 近藤恵, 久保麦野，久保大輔の諸氏の補助をいただいた。各 氏に御礼申し上げる。最後に，港川人骨の発見を実現した 大山盛保氏のゆるぎない熱意とご功績, 東京大学側で港川 フィッシャーおよび山下町第一洞穴関連の研究を担ってき た鈴木尚と渡辺直経両先生のご功績, さらには 1970 年度と 1974 年度の科学研究費補助金による調査の代表者をそれぞ れ務めた田辺義一と土隆一両先生のご功績に深く敬意を表 し, 日本の更新世人類研究の今後のさらなる研究的展開を 願い，本稿を終えることとしたい。

\section{引用文献}

馬場悠男（2000）港川人は琉球人の祖先か一島嶼適応の観 点加．高宮広衛先生古希記念論集刊行会編，琉球・東 アジアの人と文化, 高宮広衛先生古希記念論集刊行会, 沖 縄県, pp. 413-423.

馬場悠男（2002）特論 I 港川人の位置づけ. 沖縄県具志頭 村教育委員会編，具志頭村文化財調査報告書第 5 集，港 川フィッシャ一遺跡一重要遺跡確認調査報告書一, 沖縄 県具志頭村教育委員会，沖縄県，pp. 121-131.
Baba H. and Endo B. (1982) Postcranial skeleton of the Minatogawa man. In: Suzuki H. and Hanihara K. (eds.), The Minatogawa Man. University of Tokyo Press, Tokyo, pp. 61-195.

Baba H., Narasaki S., and Ohyama S. (1998) Minatogawa hominid fossils and the evolution of Late Pleistocene humans in East Asia. Anthropological Science, 106 (Supplement): 27-45.

遠藤美子・遠藤萬里（1979）東京大学総合研究資料館収蔵 日本縄文時代人骨型録. 東京大学総合研究博物館標本資 料報告 No. 3 .

長谷川善和・松岡廣繁 (2002) 第 3 章 港川フィッシャーと 動物たち．沖縄県立博物館編, 沖縄県立博物館復帰 30 周 年記念特別展「港川人展〜元祖ウチナーンチュ〜」，沖縄 県立博物館, 那覇, pp. 26-34.

Kaifu Y., Fujita M., Kono R.T., and Baba H. (2011) Late Pleistocene modern human mandibles from the Minatogawa Fissure site, Okinawa, Japan: morphological affinities and implications for modern human dispersals in East Asia. Anthropological Science, 119: 137-157.

Kobayashi H., Matsui Y., and Suzuki H. (1971) University of Tokyo radiocarbon measurements IV. Radiocarbon, 13: 97102.

Kobayashi H., Hirose T., Sugino M., and Watanabe N. (1974) University of Tokyo radiocarbon measurements V. Radiocarbon, 16: 381-387.

Kondo M. and Matsu'ura S. (2005) Dating of the Hamakita human remains from Japan. Anthropological Science, 113: 155161

Matsu'ura S. (1982) Relative dating of the Minatogawa man by fluorine analysis. In: Suzuki H. and Hanihara K. (eds.), The Minatogawa Man. The University Museum, The University of Tokyo, Bulletin, 19: 205-208.

Matsu'ura S. (1999) A chronological review of Pleistocene human remains from the Japanese Archipelago. In: Omoto K. (ed.), Interdisciplinary Perspectives on the Origins of the Japanese. International research Center for Japanese Studies, Kyoto, pp. 181-197.

松浦秀治・近藤恵 (2000) 日本列島の旧石器時代人骨はど こまで遡るか一化石骨の年代判定法. 馬淵久夫・富永健 編, 考古学と化学をむすぶ, 東京大学出版会, pp. 135-167.

Nakagawa R., Doi N., Nishioka Y., Nunami S., Yamauchi H., Fujita M., Yamazaki S., Yamamoto M., Katagiri C., Mukai H., Matsuzaki H., Gakuhari T., Takigami M., and Yoneda M. (2010) Pleistocene human remains from Shiraho-Saonetabaru Cave on Ishigaki Island, Okinawa, Japan, and their radiocarbon dating. Anthropological Science, 118: 173-183.

野原朝秀（1996）港川人について (資料). 琉球大学教育学 部紀要, 49: 85-90.

Oshiro I. and Nohara T. (2000) Distribution of Pleistocene terrestrial vertebrates and their migration to the Ryukyus. Tropics, 10: $41-50$.

大城逸朗（2001）琉球列島産第四紀陸生脊椎動物遺骸の地 質学的研究. 沖縄産古脊椎動物の研究一野原朝秀教授退 官記念論文集一, 琉球大学教育学部自然環境教育コース, 沖縄県, pp. 37-136.

佐倉朔 (1985) 第 5 章 ピンザアブ出土人骨化石. 沖縄県 教育委員会編, 沖縄県文化財調査報告書第 68 集 ピンザ アブーピンザアブ洞穴発掘調査報告書, 沖縄県教育委員 会, 沖縄県, pp. 161-176.

鈴木尚（1962）三ヶ日人と三ヶ日只木石灰岩採石場の含化 石層. 1 三ヶ日人骨. 人類学雑誌, 70: 1-20. 
鈴木尚（1966）浜北人と浜北根堅遺跡. II 浜北人の形質. 人類学雑誌, 74: 119-136.

鈴木尚（1975）沖縄に打ける洪積世人類の発見. 人類学雑 誌, 83: 113-124.

鈴木尚（1983）港川人一沖縄の洪積世人類. 成城教育，39: $1-17$.

Suzuki H. (1983) The Yamashita-cho man: A late Pleistocene infantile skeleton from the Yamashita-cho Cave (Okinawa). Bull. et Mém. de la Soc. d'Anthrop. de Paris, 10 (Série XIII): 81-87.

Suzuki H. and Hanihara K. (eds.) (1982) The Minatogawa Man: The Upper Pleistocene Man from the Island of Okinawa. The University Museum, The University of Tokyo, Bulletin, 19.

Suzuki H. and Tanabe G. (1982) Introduction. In: Suzuki H. and Hanihara K. (eds.), The Minatogawa Man: The Upper Pleis- tocene Man from the Island of Okinawa. The University Museum, The University of Tokyo, Bulletin, 19: 1-5.

高宮広衛・金武正紀・鈴木正男（1975）那覇市山下町洞穴 発掘経過報告. 人類学雑誌, 83: 125-130.

Trinkaus E. and Ruff C.B. (1996) Early modern human remains from eastern Asia: The Yamashita-cho 1 immature postcrania. Journal of Human Evolution, 30: 299-314.

渡辺直経 (1971) 沖縄に打ける洪積世人類化石の新発見. 人 類科学, 23: 207-215.

渡辺直経（1973）沖縄に打ける洪積世人類遺跡の調査. 南 島考古，3:1-4.

渡辺直経（1980）沖縄に打ける洪積世人類遺跡. 第四紀研 究, 18: 259-262. 